\title{
Laiduntavien lypsylehmien jatkuva pötsin pH:n mittaaminen
}

\author{
Elina Juutinen ${ }^{1)}$, Auvo Sairanen ${ }^{1)}$ Arja Korhonen ${ }^{2)}$ \\ 1) Maa- ja elintarviketalouden tutkimuskeskus, Kotieläintuotannon tutkimus, Halolantie 31 A, 71750 \\ Maaninka, etunimi.sukunimi@mtt.fi
}

2)Savonia-ammattikorkeakoulu, PL 72, Haukisaarentie 2, 74101 Iisalmi, etunimi.sukunimi@savonia.fi

\section{Tiivistelmä}

Pötsin $\mathrm{pH}$ asettaa rajat korkeatuottoisen lypsylehmän ruokinnan suunnitteluun. $\mathrm{pH}: n$ yläraja tulee vastaan ruokintahäiriötapauksissa, esimerkiksi ureamyrkytyksessä. Pötsin $\mathrm{pH}: n$ alaraja saavutetaan ruokinnan intensiteettiä nostettaessa, kun tavoitellaan mahdollisimman suurta maitotuotosta tai ruokinnallisissa virheissä. Maitotuotosintensiteetin nosto tapahtuu nurmirehun sulavuuden ja/tai väkirehumäärän noston avulla.

Koetoiminnassa parsinavetan kokoaikalaiduntavien lehmien väkirehun jako on onnistunut 12 kiloon/vrk saakka, kun väkirehut on jaettu aamu ja iltalypsyn yhteydessä heti sisälle oton jälkeen ja juuri ennen laitumelle laskua. Jakokertoja tulee tällöin neljä kpl/vrk. Lypsyasemanavetassa kokoaikalaiduntavilla lehmillä on vain kaksi väkirehun jakokertaa vuorokaudessa. Ongelmana voi olla pötsin pH:n lasku, mikä voi johtaa hapanpötsiin. Seurauksena on syönnin ja maitotuotoksen pieneneminen ja mm. sorkkasairauksien riski lisääntyvät. Osa-aikalaiduntaville väkirehu voidaan jakaa useamman kerran päivässä, jolloin väkirehun kertaannos on pieni. Rehun valkuainen puskuroi pötsin $\mathrm{pH}: \mathrm{n}$ muutosta, joten valkuaisen lisääminen voi pienentää pötsin pH:n muutoksia.

Maitotiloilla ei ole rutiininomaista mittaustapaa pötsin pH:n määrittämiseen. pH:n muutosten tutkiminen on mahdollista pötsiin laitettavien jatkuvatoimisten pH-bolusten avulla. Tässä kokeessa käytettiin jatkuvatoimisia smaXtec $\mathrm{pH}$-boluksia (smaXtec animal care $\mathrm{GmbH}$, Itävalta), joiden valmistajan takaama käyttöaika on 50 vrk, $\mathrm{pH}: n$ mittaustarkkuus $\pm 0,1 \mathrm{pH}$ yksikköä.

Tämän tutkimuksen tavoitteena oli tutkia soveltuvatko pH-bolukset lypsylehmien normaaliin ruokinnan seurantaan sekä suuren väkirehun kerta-annoksen vaikutusta pötsin $\mathrm{pH}$ tasoon laidunruokinnalla (koe 1). Lisäksi tavoitteena oli tutkia osa- ja kokoaikalaidunnuksen sekä väkirehun valkuaispitoisuuden vaikutusta pötsin $\mathrm{pH}$ tasoon vuorokauden eri aikoina kokoaikalaiduntavilla lehmillä (KL) verrattuna yöaikaan laiduntaviin lehmiin (OL), kun väkirehun määrä oli vakio (koe 2).

Kokeen 1 perusteella 6 kilon väkirehumäärän jako kerta-annoksena lypsyasemalla on liian suuri ja altistaa lehmät syöntihäiriölle. Kokeen 2 perusteella 4,5 kilon väkirehuannos ei tuottanut vielä ongelmia. Yksittäisen pH-boluksen mittaaman aikasarjan perusteella $\mathrm{pH}$-bolusten tulokset osoittautuivat peräkkäisten mittausten osalta luotettaviksi. Jatkuvatoimisia $\mathrm{pH}$-boluksia suositellaan kustannussyistä sijoitettavaksi vain osalle lehmistä. Tämä ei tuota riittävästi tietoa tunnistamaan karjan riskiryhmässä olevia lehmiä. Dieetin komponenttien perusteella voitaisiin tuottaa ennustemalli keskimääräisen $\mathrm{pH}$-tason arvioimiseksi, joten bolusten arvo on nimenomaan yksilötason erojen määritys. Laiduntamisaika tai väkirehun valkuaispitoisuus eivät merkittävästi vaikuttaneet pötsin $\mathrm{pH}$-tasoon.

Asiasanat: asidoosi, pH, pH-bolus, laiduntaminen, lypsylehmä, väkirehu 


\section{Johdanto}

Laiduntavilla lehmillä normaali pH:n vaihtelu on välillä 5,8-7 (Kolver \& de Veth 2002, Sairanen julkaisematon). Asidoosista (hapanpötsi) voidaan puhua, kun pötsin pH laskee alle 5,5 (Krause \& Oetzel 2006). Subakuutti asidoosi määritellään tilaksi, jossa pötsin $\mathrm{pH}$ on matalalla tasolla useita tunteja päivässä. Yksiselitteisiä pH-rajoja tälle ei ole esitetty (Plaizier ym 2009). Subakuutti asidoosi on yleisintä vasta poikineilla lehmillä, joiden syöntikyky ei ole vielä kehittynyt ja joiden väkirehumäärät ovat suuria (Duffield ym. 2004). Sitä on esiintynyt $19-26 \%$ :lla lehmistä alku- ja keskilaktaation aikana. Oireina on syömättömyys, maitotuotoksen lasku, laihtuminen, märehtimisen väheneminen sekä hidastunut pötsin toiminta. Matala pötsin $\mathrm{pH}$ lisää riskiä sairastua sorkka- ja muihin tuotannollisiin sairauksiin ja maitotuotos voi laskea (Plaizier ym. 2009).

Rehun sisältämä suuri solunsisällyshiilihydraattien määrä aiheuttaa pötsissä nopean fermentaation, jolloin $\mathrm{pH}$ laskee. Pötsin pH voi olla matala myös laiduntavilla eläimillä etenkin korkeita väkirehumääriä käytettäessä (Owens ym. 1998). Koetoiminnassa kokoaikalaiduntavien lehmien väkirehun jako on parsinavetassa onnistunut 12 kiloon/vrk saakka, kun väkirehut jaetaan aamu- ja iltalypsyn yhteydessä heti sisälle oton jälkeen ja juuri ennen laitumelle laskua (Sairanen julkaisematon). Lypsyasemanavetassa kokoaikalaiduntavilla lehmillä on vain kaksi väkirehun jakokertaa vuorokaudessa. Kaksi kertaa vuorokaudessa tapahtuvan jaon ongelmana voi olla pötsin pH:n lasku normaalia alemmaksi, mikä voi johtaa asidoosiin. Osaaikalaiduntajille väkirehu voidaan jakaa useamman kerran päivässä, jolloin väkirehun kerta-annos on pienempi. Rehun valkuainen puskuroi pötsin $\mathrm{pH}: \mathrm{n}$ muutosta, joten valkuaisen lisääminen voi pienentää pötsin pH:n muutoksia.

Käytännössä pötsin pH voidaan mitata pötsin nahan läpi työnnettävällä pistimellä tai nielun kautta otetusta pötsinestenäytteestä. Kumpikaan menetelmä ei sovellu rutiinimääritykseen. Matala rasvapitoisuus maidossa voi olla myös merkki matalasta pötsin $\mathrm{pH}$ :sta, mutta maidon rasvapitoisuuden aleneminen on näkynyt vaihtelevasti aikaisemmassa kokeessa (Krause \& Oetzel 2005) ja rutiininäytteitä otetaan tavallisesti liian harvoin tunnistamaan pötsin $\mathrm{pH}: \mathrm{n}$ muutokset.

Pötsin pH:n mittausta varten markkinoille on tullut myös pötsiin nielun kautta sijoitettavia jatkuvatoimisia pH -boluksia, joiden toiminnasta ovat raportoineet mm. Mottram ym. (2008) ja Kilic ym. (2011). Pötsin $\mathrm{pH}$ voi vaihdella hieman pötsin eri osissa (Mottram ym. 2008), joten boluksen liikkuminen pötsissä voi vaikuttaa tulokseen. Kalibroidun $\mathrm{pH}$-boluksen mittaustarkkuus on korreloinut hyvin $\left(\mathrm{R}^{2}=0,87,0,85,0,89\right)$ mitatun pH:n kanssa (Dado \& Allen 1993, Penner ym. 2006, 2009). Toistaiseksi laitteistot ovat kalliita ja niiden käyttöaika tämänhetkisellä tekniikalla $1-2$ kuukautta. Lehmälle ei voi sen elinaikana laittaa kuin kaksi bolusta, koska ne ajautuvat verkkomahaan ja saattavat haitata verkkomahan toimintaa suurempina lukumäärinä.

Tämän tutkimuksen tavoitteena oli tutkia soveltuvatko jatkuvatoimiset pH-bolukset lypsylehmien normaaliin ruokinnan seurantaan (kokeet 1 ja 2). Toinen tavoite oli tutkia bolusmittauksen avulla lypsyasemalla jaettavan väkirehun kerta-annoksen vaikutusta pötsin $\mathrm{pH}$ tasoon laidunruokinnalla (koe 1). Lisäksi tavoitteena oli tutkia osa- ja kokoaikalaidunnuksen sekä väkirehun valkuaispitoisuuden vaikutusta pötsin $\mathrm{pH}$ tasoon vuorokauden eri aikoina kokoaikalaiduntavilla lehmillä (KL) verrattuna yöaikaan laiduntaviin lehmiin (OL), kun väkirehun määrä oli vakio (koe 2). Jälkimmäisen tutkimuksen rehun syönti- ja maitotuotostulokset on raportoitu Maataloustieteiden päivillä 2012 julkaisussa Sairanen ym. (2012). Tutkimus oli osana NYT Nykyaikainen navettateknologia -hanketta (MTT), jonka rahoittajana ovat Pohjois-Savon liitto (Euroopan aluekehitysrahasto) ja Pohjois-Savon elinkeino-, liikenne- ja ympäristökeskus (Euroopan sosiaalirahasto).

\section{Aineistot ja menetelmät}

Näissä kokeissa käytettiin smaXtec pH-boluksia (smaXtec animal care $\mathrm{GmbH}$, Itävalta), joiden valmistajan takaama käyttöikä on 50 vrk ja pH:n mittaustarkkuus $\pm 0,1$ pH yksikköä. Mittausväli säädettiin 10 minuutin jaksoihin. Bolukset asennettiin 10 eläimelle nielun kautta 15.6.2011 ja kokeet loppuivat 10.8.2011 eli mittausaika oli 56 vrk. Bolusdatat luettiin lypsyasemalle kiinnitetyllä lukijalaitteella kaksi kertaa päivässä lypsyn yhteydessä, jonka avulla pötsin pH:ta voitiin seurata lähes reaaliaikaisesti. 


\section{Koe 1: Väkirehun noston vaikutus pH-tasoon ja pH-bolusten käyttäminen ruokinnan seurannassa}

Koe suoritettiin 20. - 29.6.2011. Ruokintakokeessa oli kuusi useamman kerran poikinutta lypsylehmää ja neljä ensikkoa, joiden poikimisesta oli kulunut $80 \pm 23$ pv ja maitotuotos oli kokeen alkaessa 35,3 \pm 7,2 $\mathrm{kg} / \mathrm{pv}$. Koelehmät totutettiin ennen koetta yölaiduntajina laidunruokintaan kolmen päivän ajan, jonka jälkeen ne olivat kokoaikalaiduntajia kahden päivän ajan ohran määrän ollessa $6 \mathrm{~kg} / \mathrm{pv}$. Eläimet olivat kokoaikaisesti laitumella lukuun ottamatta lypsyjä (lypsy klo 7:50 - 8:30 ja 16:30 - 17:10) ja laidunnusaika oli noin 18,5 h/vrk. Laidunala mitoitettiin niin, että laidunta oli tarjolla vähintään $25 \mathrm{~kg} \mathrm{ka} / \mathrm{ha} / \mathrm{lehmä/vrk}$.

Lehmät saivat litistettyä ohraa (Taulukko 1) kaksi kertaa päivässä lypsyn yhteydessä lypsyasemalla sekä kivennäisiä vapaasti laitumella. Väkirehun määrä oli kokeen alussa $6 \mathrm{~kg} / \mathrm{vrk}$ ja sitä nostettiin kilo/vrk 12 kiloon/vrk asti ja väkirehuannos pyrittiin pitämään neljä päivää 12 kilossa/vrk. Väkirehua jaettaessa valvottiin, etteivät lehmät varastaneet väkirehua toiselta lehmältä ja mahdolliset väkirehutähteet punnittiin. Lehmien pötsin pH:ta, väkirehun syöntiä ja yleistä hyvinvointia tarkkailtiin päivittäin ja jos lehmä jätti väkirehua syömättä yli $2 \mathrm{~kg} / \mathrm{vrk}$ tai pH oli alle 5,5 väkirehutasoa pudotettiin ja laitumen lisäksi eläin sai kuivaa heinää, jolloin eläin ei ollut enää kokeessa.

Maitomäärät mitattiin päivittäin ja maitonäytteet otettiin aamulla ja illalla ja niistä analysoitiin rasva (Valio Oy). Laidunnurmen alkumassa ennen laiduntamista mitattiin aamulla kuutena peräkkäisenä päivänä. Laidunruohosta leikattiin satunnaisesti neljän kehikon $(20 \times 50 \mathrm{~cm})$ alalta kasvusto $6 \mathrm{~cm}: n$ korkeuteen. Näytteet punnittiin ja kuivattiin $60^{\circ} \mathrm{C}: \mathrm{ssa} 48 \mathrm{~h}$ ja yhdistettiin jakson lopussa. Ohrasta otettiin joka päivä näyte ja osanäytteet yhdistettiin kokeen lopussa. Yhdistetystä näytteestä analysoitiin tuhka, raakavalkuainen, orgaanisen aineen sellulaasiliukoisuus (vain laidunruohosta) ja NDF MTT:n Kotieläintuotannon tutkimuksen laboratoriossa.

Taulukko 1. Laidunruohon ja ohran rehuarvo kokeessa 1.

\begin{tabular}{lcc}
\hline & Laidunruoho & Ohra \\
\hline \hline Laidunmassa kg ka/ha & $1968 \pm 198$ & \\
Kuiva-aine g/kg & 180 & 870 \\
Kuiva-aineessa, g/kg & & \\
Tuhka & 80,1 & 24,3 \\
Raakavalkuainen & 188 & 115 \\
Neutraalidetergenttikuitu & 560 & 198 \\
Rehuarvot & & \\
D-arvo, g/kg ka & 664 & \\
ME, MJ/kg ka & 10,6 & 13,3 \\
OIV, g/kg ka & 91,6 & 97,0 \\
PVT, g/kg ka & 55,0 & $-30,7$ \\
\hline
\end{tabular}

\section{Koe 2: Laidunnusajan ja väkirehun valkuaispitoisuuden vaikutus pötsin pH-tasoon}

Koe suoritettiin välillä 30.6. - 10.8.2011. Koejäseninä käytettiin laidunaikaa (osa-aikainen; OL ja kokoaikalaidun; KL) sekä kahta väkirehun raakavalkuaispitoisuutta (matala MRV 153 g/kg ka, korkea KRV 197 g/kg ka). Koeasetelmana oli kaksijaksoinen cross overin (valkuaismuuttuja) ja satunnaistettujen lohkojen (laidunaikamuuttuja) yhdistelmä. Yhden koejakson pituus oli 15 päivää ja jaksoja oli kaksi. Tulosten laskennassa käytettiin jaksojen viiden viimeisen päivän $\mathrm{pH}$-arvoja. Lisäksi lehmien pötsin $\mathrm{pH}$-taso otettiin huomioon tulosten laskennassa ennen varsinaista koetta12 päivää kestäneen mittausjakson viimeisiltä viideltä päivältä (=kovariaattijakso).

Kokeessa oli 36 lypsylehmää, joista 18 oli osa-aikalaiduntajia (OL) ja 18 kokoaikalaiduntajia (KL). Koeasetelmana oli kaksijaksoinen cross overin (valkuaismuuttuja) ja satunnaistettujen lohkojen (laidunaikamuuttuja) yhdistelmä. Väkirehuannos oli koko kokeen ajan $9 \mathrm{~kg} / \mathrm{pv}$ ja väkirehuna oli ohraa ja rypsiä. OL- 
ryhmä sai aamulypsyllä 4,5 kg väkirehua ja 4,5 kg päivän aikana väkirehukioskista jaettuna kahteen annokseen. KL-ryhmä sai 4,5 kg annoksen väkirehua aamu- ja iltalypsyn yhteydessä lypsyasemalla. Lypsy oli aamulla noin klo 6:30 - 8:00 ja illalla noin klo 15:30 - 17:00 välillä.

Tarjolla olevan laitumen määä oli OL-ryhmällä 0,6 aaria/lehmä/pv ja KL-ryhmässä 1,0 aari/lehmä/pv ja laidunnusaika oli OL-ryhmällä 12,5 h/vrk ja säilörehua oli tarjolla navetassa 9,5 h/vrk. KL-ryhmän laidunnusaika oli noin 18,5 h/vrk. Laitumen massa mitattiin kahdeksana peräkkäisenä päivänä jaksojen lopussa kehikkomittausmenetelmällä $6 \mathrm{~cm}: n$ korkeuteen ennen kuin lehmät pääsivät laitumelle. Laitumen massa oli 1. jaksolla $2234 \pm 235$ ja 2 . jaksolla $2614 \pm 669 \mathrm{~kg} \mathrm{ka} / \mathrm{ha}$. Lehmät saivat uuden kaistan laidunnettavaksi joka päivä. Leikatuista laidunnäytteistä ja keruujaksoilta kerätyistä väkirehunäytteistä analysoitiin rehuarvot ja säilörehusta lisäksi säilönnällinen laatu. Tarkempi koeasetelma sekä kokeen 2. rehunäytteiden analyysitulokset on kuvattu Sairanen ym. (2012) Maataloustieteiden päivien artikkelissa.

Tulokset laskettiin SAS 9.2:n Mixed-proseduuria käyttäen. Tilastomallissa oli mukana ennen koetta mitattu muuttujan kovariaattiarvo, eläin, jakso, laidunaika (OL- ja KL), lisävalkuaistaso (MRV, KRV) sekä laidunajan ja valkuaistason yhdysvaikutus (Laidun*RV). Laidunajan suhteen malli oli toistettujen mittausten koe, jossa jakso oli toistotekijä. Kellonaika * Laidun -yhdysvaikutuksen testaamiseksi mallissa oli mukana eläin, laidunaika, mittauskellonaika. Kellonajan suhteen testi oli toistettujen mittausten koe. pH arvoina käytettiin jaksojen keskiarvoa.

\section{Tulokset ja tulosten tarkastelu}

\section{Koe 1. Väkirehun noston vaikutus pH-tasoon ja pH-bolusten käyttäminen ruokinnan seurannassa}

Laidunrehun D-arvo oli $664 \mathrm{~g} / \mathrm{kg}$ ka eli sulavuus oli matala verrattuna suositusten mukaiseen laitumeen. Matala D-arvo on voinut lieventää pötsin $\mathrm{pH}$ muutoksia. Kokeessa ruokintahäiriön rajana pidettiin $\mathrm{pH}: t a 5,5$, koska tämän rajan alapuolella maitohapon muodostuminen lisääntyy voimakkaasti. Kaksitoista kiloa valittiin rajaksi, koska aiemmissa kokeissa (Sairanen julkaisematon) vastaava määrä ei ole tuottanut ongelmia parsinavetassa kokoaikalaiduntavilla lypsylehmillä, kun väkirehut on jaettu sisälle oton ja laitumelle laskun yhteydessä (4 jakokertaa/vrk: laitumelta tultaessa ja laitumelle lähdettäessä). Aikaisemmat väkirehutasokokeet on toteutettu sekä teollisella väkirehulla, että kotiseoksella (ohra-kaura-ohrarehu-rypsi seos).

Kahdestatoista kokeen aloittaneesta lehmästä vain kolme pääsi 12 kilon maksimimäärään saakka ja näistä vain eläimet nro 29 ja 98 söivät neljä päivää väkirehunsa ongelmitta. Näiden lehmien pötsin pH oli kyseisten neljän päivän keskiarvona 6,24 $\pm 0,31$ ja 6,30 $\pm 0,35$. Syöntihäiriöt muilla eläimillä alkoivat keskimäärin 10 kilon väkirehumäärällä, jolloin merkittävämpää syöntijätettä mitattiin neljältä lehmältä. Yhdentoista kilon syöntimäärällä väkirehutähteitä kirjattiin peräti 8 lehmältä. Tässä tapauksessa ilmeisesti kilon päivässä tapahtunut väkirehun nosto oli liian nopea. Aikaisemmassa viljaväkirehuun perustuvassa kokeessa (Sairanen, julkaisematon) käytettiin ruokintajakson muuttuessa samaa kilon muutosnopeutta ja kokeessa maksimi väkirehumäärä oli myös $12 \mathrm{~kg}$. Kokeessa oli lisäksi pelkän viljan lisäksi ohrarehua ja rypsiä. Tässä aiemmin tehdyssä kokeessa ei ollut väkirehujätettä suuria määriä (keskimäärin $0,2 \mathrm{~kg} / \mathrm{vrk} 12 \mathrm{~kg}$ dieetillä), joten nostonopeus ei sinällään ole mitenkään poikkeuksellisen suuri.

Maidon rasvapitoisuus pieneni keskimäärin 7,3 $\pm 1,8 \mathrm{~g} / \mathrm{kg}(\mathrm{n}=6)$ sen jälkeen lehmillä oli kirjattu väkirehun syöntihäiriö. Pötsin pH:n aleneminen ja maidon rasvapitoisuuden lasku esiintyivät jokseenkin samanaikaisesti. Rasvapitoisuuden lasku oli suurempi verrattuna Stonen (1999) kokeeseen, jossa pitoisuus aleni 3,0 g/kg maitoa. Maidon rasvapitoisuuden muutoksilla olisi käyttöä pötsiolosuhteiden kuvaamiseen, mikäli käytössä olisi sopiva pikamittausjärjestelmä. Laboratorioanalyysit ovat liian työläitä tähän tarkoitukseen.

Yksittäiset lehmät reagoivat hyvin vaihtelevasti mataliin pötsin $\mathrm{pH}$-arvoihin. Kuvassa 1. on kolme esimerkkiä väkirehujätettä jättäneistä lehmistä eri päiviltä. Lehmän nro 3348 pötsin $\mathrm{pH}$-arvo oli melko matala (keskiarvo ennen koetta) jo kokeen alkaessa, mutta vasta yhdeksän kilon väkirehuannoksella pH laski alle 5,5. Lehmä lopetti väkirehun syömisen vasta, kun taso oli $11 \mathrm{~kg} / \mathrm{vrk}$. Vastaavasti lehmä nro 69 jätti huomattavan määrän väkirehujätettä 10 kilon päivittäisellä annostustasolla. Kyseisen lehmän pötsin pH kävi edellisenä päivänä hetkellisesti 5,7 tasolla. Lehmä nro 4263 ei syönyt 12 kilon väkirehumäärää. Kyseisellä lehmän syömättömyyttä ei voitu päätellä päivittäisistä pötsin $\mathrm{pH}: n$ muutoksista ja matalin pötsin $\mathrm{pH}$ ennen 12 kilon väkirehuannosta oli 6,4 . 


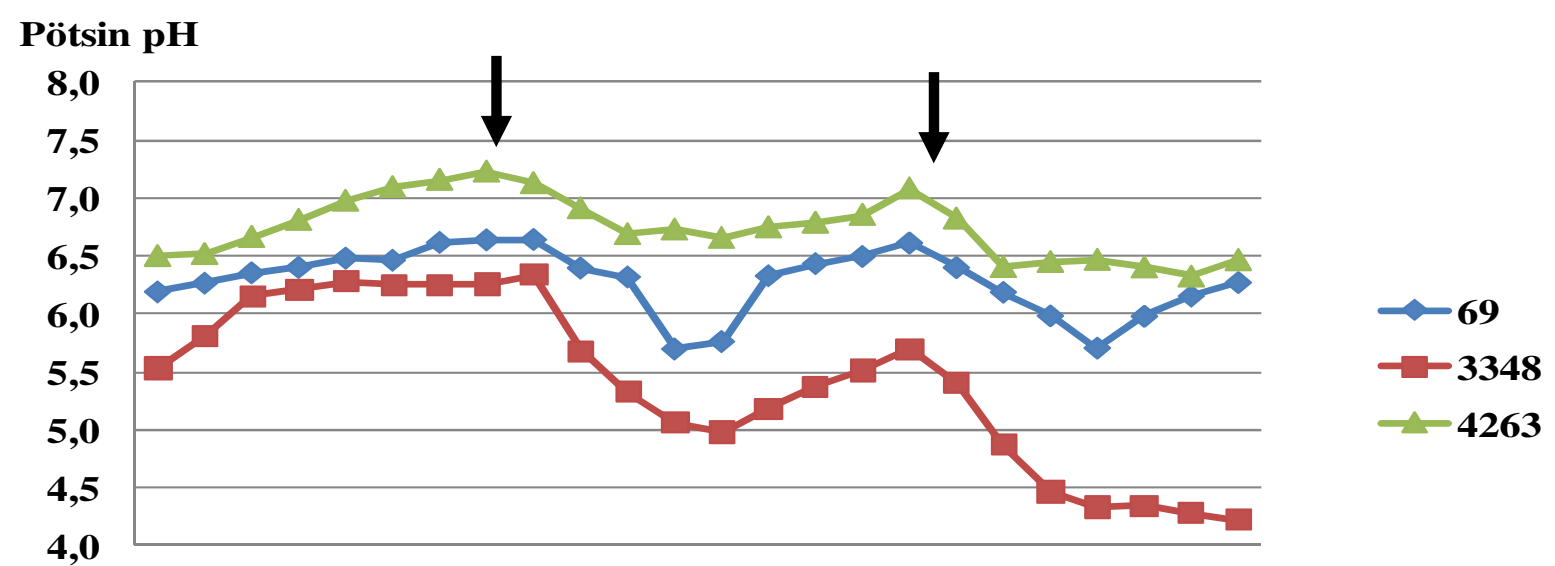

$\begin{array}{lllllllllllll}0 & 1 & 2 & 3 & 4 & 5 & 6 & 7 & 8 & 9 & 1011 & 121314151617181920212223\end{array}$ Kellonaika

Kuva 1. Pötsin pH:n kehitys kolmelta eläimeltä vuorokauden tuntikeskiarvoina laskettuna. Nuolet osoittavat keskimääräiset väkirehunantohetket. Tulokset ovat väkirehun syöntihäiriötä edeltäneeltä päivältä. Lehmien 69 ja 4263 pötsin pH luvut eivät häiriöpäivinä oleellisesti eronneet tässä esitetystä, mutta lehmän 3348 söi rehunsa vaikka pötsin pH oli vaarallisen alhainen.

Tämän kokeen perusteella lehmät yleensä tunnistavat liian matalan $\mathrm{pH}$ arvon ja pH:n äkillinen aleneminen aiheuttaa usein väkirehun syönnin rajoittumisen seuraavana päivänä. Syönnin aleneminen on raportoitu myös muualla kirjallisuudessa ja se on seurausta pötsin haituvien rasvahappojen määrän ja osmolaarisuuden muutoksista (Plaizier ym. 2009). Syödyn tärkkelyksen määrän väheneminen rajoittaa pötsifermentaatiota ja haihtuvien rasvahappojen (VFA:n) määrää, joten osa lehmistä hoiti hapanpötsiä vähentämällä väkirehun syöntiä. Kuitenkin hapanpötsistä voi jäädä pitkäaikaisempia vaikutuksia, joten sitä tulisi pyrkiä ennaltaehkäisemään. Yksilökohtaisista eroista johtuen toiset lehmät reagoivat liialliseen helppoliukoisten hiilihydraattien määrään liian hitaasti. Lehmien välillä on ilmeisesti eroja myös $\mathrm{pH}: n$ puskurointikapasiteetissa. Yksilökohtaisista eroista johtuen lehmille ei voi määrittää yhtä väkirehun kerta-annoksen maksimirajaa, joka olisi niille turvallinen. Jatkuvatoimisen pH mittauksen avulla lehmää voi käyttää omana kontrollinaan ja silloin pH:n muutos kertoo ruokintahäiriön riskin mahdollisuudesta.

\section{Koe 2. Laidunnusajan ja väkirehun valkuaispitoisuuden vaikutus pötsin pH-tasoon}

Lehmien syönti on aktiivisinta illalla ja yön aikana lehmien syöntiaktiivisuus pienenee (Sairanen ym. 2012). Yön aikana pötsimikrobit fermentoivat rehun helppoliukoisimmat hiilihydraatit VFA:ksi ja aamua kohti mentäessä pötsin sisällön kuituosuus lisääntyy. VFA imeytyy nopeasti verenkiertoon, joten pötsin rasvahappopitoisuus laskee aamua kohti mentäessä. Tämä näkyy pötsin $\mathrm{pH}: n$ nousuna aamulla (kuva 2), mikä tukee aikaisempia tutkimuksia (Duffield ym. 2004). Navettaan oton yhteydessä lehmille jaettiin väkirehu, joka toi helppoliukoista tärkkelystä mikrobien saataville. Lypsyn jälkeen KL-lehmät laskettiin laidunlohkolle, jossa ei ollut laidunnettu. Aktiivisen laitumen syönnin seurauksena pötsin helppoliukoisten hiilihydraattien määrä nousi edelleen, mikä näkyi KL-ryhmän pötsin pH:n laskuna aina klo 12 saakka. Tämän jälkeen pötsin $\mathrm{pH}$ alkoi taas nousta noin klo 15 saakka. Illalla noin klo 16 eläimet saivat uuden annoksen väkirehua. Väkirehuannos yhdessä aktiivisen iltasyönnin kanssa laski pötsin pH:n matalimmilleen klo 20 aikaan, jonka jälkeen $\mathrm{pH}$ alkoi taas nousta tasaisesti aina aamuruokintaan saakka.

Osa-aikalaiduntajilla pH:n muutokset olivat yökauden osalta lähes identtiset kokoaikalaiduntajiin nähden. Yön osalta molempien ryhmien lehmät ovat samalla ruokinnalla, joten tulos on luonteva. Aamuväkirehuruokinnan jälkeen pötsin pH OL-ryhmässä lukuarvoisesti pysyi tasaisempana kuin KL-ryhmässä (aika * laidunaika -yhdysvaikutus $\mathrm{P}<0,001$ ). Osa-aikalaiduntaja lehmät saivat väkirehu väkirehukioskista päivän aikana, mikä on todennäköisesti ylläpitänyt tasaista pötsin $\mathrm{pH}$ :ta. Numeroarvoisista tuntikohtaisista eroista huolimatta OL- ja KL-laiduntajien pötsin pH oli samalla tasolla koko päivän keskiarvona, 6,63 $\pm 0,103$ ja kokoaikalaiduntajilla 6,51 $\pm 0,09(\mathrm{P}=0,42)$. Väkirehun valkuaispitoisuus ei myöskään vaikuttanut pötsin $\mathrm{pH}$ tasoon $(\mathrm{P}=0,28)$, pötsin $\mathrm{pH}: n$ ollessa KRV-ryhmässä 6,53 $\pm 0,074$ ja MRV-ryhmässä 6,61 $\pm 0,074$. Valkuaisen hajoamistuotteena oleva urea on emäksistä, mutta ilmeisesti kokeessa käytetty rypsirouhemäärä on liian pieni, että valkuaisen vaikutus olisi näkynyt $\mathrm{pH}$ :ssa. Kaiken kaikkiaan pötsin $\mathrm{pH}$ oli molemmilla ryhmillä 
maltillinen ja 4,5 kilon kerta-annos on näiden tulosten perusteella lehmille turvallinen myös kokoaikalaiduntajille kahtena vuorokausiannoksena.

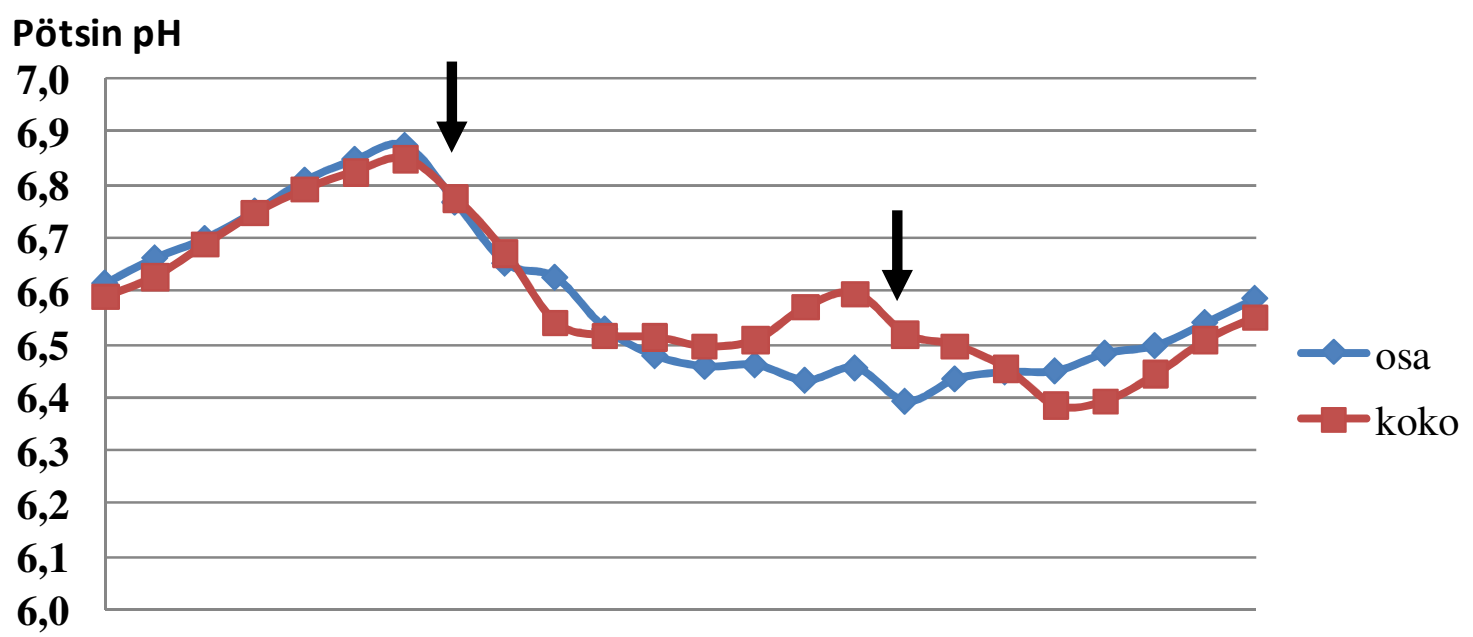

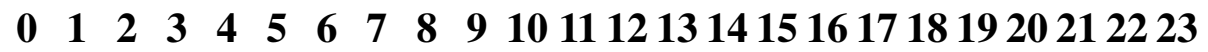

Kellonaika

Kuva 2. Laidunajan vaikutus pötsin pH tasoon. Nuolet osoittavat keskimääräiset väkirehunantohetket.

Lehmien väliset erot pötsin pH:ssa ovat suuria. Kuvassa 3 on esitetty kaikkien lehmien vuorokausi pH keskiarvot 1. ja 2. jaksojen viimeisten viiden päivän keskiarvona. Yhden pH yksikön ero lehmien välillä on huomattava. Käytännössä tämä tarkoittaa sitä, että dieetin tuottama keskimäärin turvallinen pH karjassa ei takaa yksittäisen lehmän kohdalla ruokinnan turvallisuutta. Tässä kokeessa matalin arvo on yli 5,8 eli kokeen mukainen ruokinta on pötsin pH:n kannalta tarkasteltuna hyväksyttävä. Alle 5,8 olevia arvoja oli koko aikana 0 - $2 \%$ molemmissa laidunryhmissä. Tilanne voi muuttuu huonommaksi, mikäli väkirehun määrää nostetaan kokeessa käytettyä suuremmaksi. Tämän vuoksi hintaluokaltaan edullisella lehmäkohtaisella pH mittauksella olisi käyttöarvoa. Lehmillä, joilla on matala pötsin $\mathrm{pH}$, ruokinnan intensiteetti voitaisiin laskea karjan keskiarvoa pienemmäksi.

Jatkuvatoimisia $\mathrm{pH}$-boluksia suositellaan kustannussyistä sijoitettavaksi vain osalle lehmistä. Tämä ei tuota riittävästi tietoa tunnistamaan karjan riskiryhmässä olevia lehmiä tämän kokeen perusteella. Dieetin komponenttien perusteella voitaisiin tuottaa ennustemalli keskimääräisen $\mathrm{pH}$-tason arvioimiseksi, joten bolusten arvo on nimenomaan yksilötason erojen määritys. Fistelöimättömillä lehmillä tehdyn kokeen vuoksi tässä tutkimuksessa ei voitu testata, onko kuvan 3. mukainen vaihtelu peräisin lehmistä, vai onko kyse mittalaitteen välisestä erosta. Peräkkäisiä päiviä tarkasteltaessa yksittäiset bolukset tuottavat toistettavaa tietoa, minkä perusteella laitteiston voidaan olettaa toimivan luvatulla tavalla. Toisella jaksolla mittarit olivat kokeessa viisi päivää yli bolusten valmistajan myöntämän takuuajan, mutta tuona aikana ei ollut havaittavissa suurta pH:n muutosta eläinkohtaisesti alle 50 päivän arvoihin verrattuna. Valmistajan antamaan vakuuteen nähden yhden $\mathrm{pH}$-yksikön vaihtelu on suuri ja tämän perusteella vaihtelulähteen voisi olettaa olevan peräisin eläimestä itsestään. Hinta ja toiminta-aika huomioiden laitteiston käyttöarvo ei yllä toistaiseksi täyttämään maidontuotantotilojen tarvetta. 


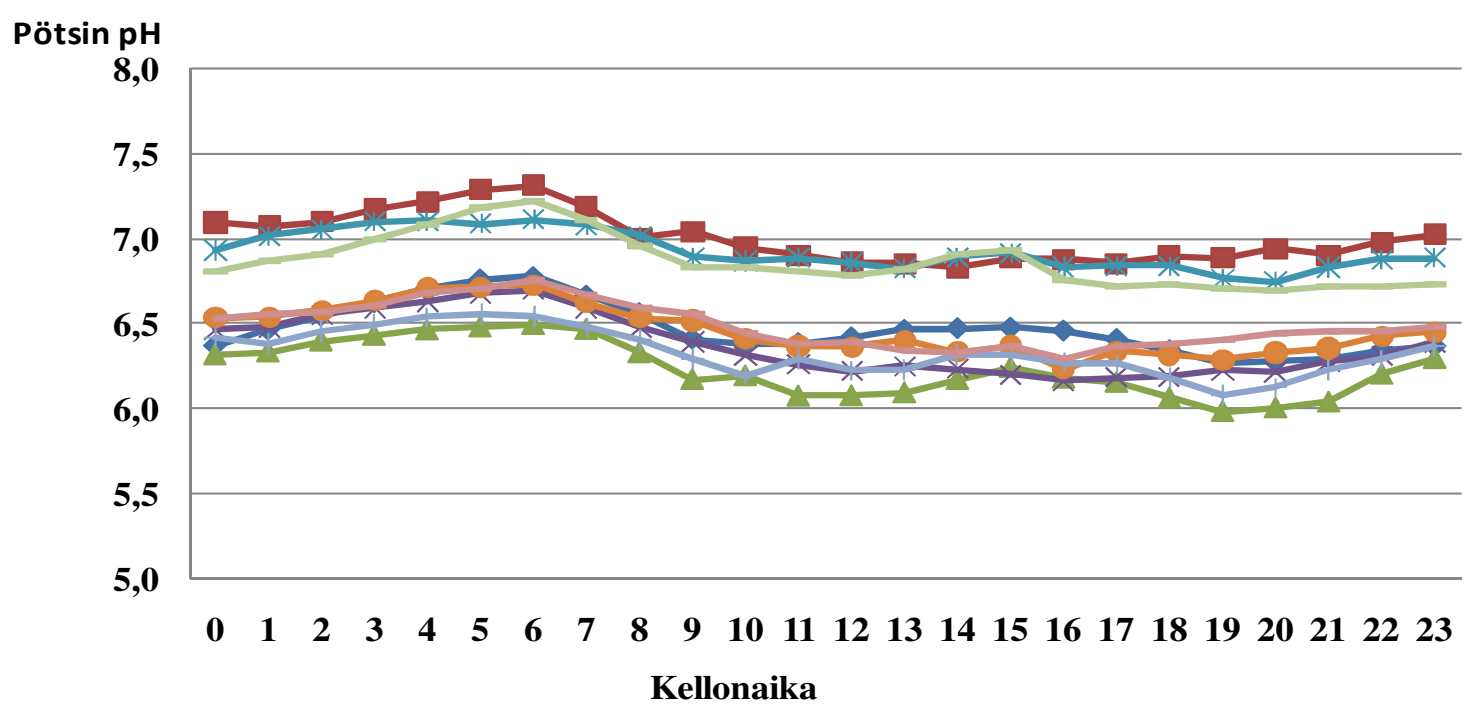

Kuva 3. Pötsin pH:n muutos vuorokauden aikana eläinkohtaisesti

\section{Johtopäätökset}

Kokeen 1 perusteella 6 kilon viljaväkirehumäärän jako kerta-annoksena lypsyasemalla on liian suuri ja altistaa lehmät syöntihäiriölle. Kokeen 2 perusteella 4,5 kilon väkirehuannos ei tuota vielä ongelmia. Yksittäisen pH-boluksen mittaaman aikasarjan perusteella $\mathrm{pH}$-bolusten tulokset osoittautuivat peräkkäisten mittausten osalta luotettaviksi. Jatkuvatoimisia $\mathrm{pH}$-boluksia suositellaan kustannussyistä sijoitettavaksi vain osalle lehmistä. Tämä ei tuota riittävästi tietoa tunnistamaan karjan riskiryhmässä olevia lehmiä tämän kokeen perusteella. Dieetin komponenttien perusteella voitaisiin tuottaa ennustemalli keskimääräisen $\mathrm{pH}$-tason arvioimiseksi, joten bolusten arvo on nimenomaan yksilötason erojen määritys. Laiduntamisaika tai väkirehun valkuaispitoisuus eivät merkittävästi vaikuttaneet pötsin $\mathrm{pH}$-tasoon vuorokausikeskiarvona. Päiväaikaan osaaikalaiduntajien pötsin $\mathrm{pH}$ oli kokoaikalaiduntajia tasaisempi.

\section{Kirjallisuus}

Dado, R.G. \& Allen, M.S. 1993. Continous computer acquisition of feed and water intakes, chewing, reticular motility and ruminal pH of cattle. Journal of Dairy Science, 76: 1589-1600.

Duffield, T., Plaizier J. C., Fairfield, A., Bagg, R., Vessie, G., Dick, P., Wilson, J., Aramini, J. \& McBride, B. 2004. Comparison of Techniques for Measurement of Rumen pH in Lactating Dairy Cows. Journal of Dairy Science 87:5966.

Krause, K.M. \& Oetzel, G.R., 2005. Inducing subacute ruminal acidosis in lactating dairy cows. Journal of Dairy Science 88, 3633-3639.

Krause, KM \& Oetzel, GR. 2006. Understanding and preventing subacute acidosis in dairy herds: A review. Animal feed science and technology, 126, 215-236.

Kilic, U. 2011. Use of wireless rumen sensor in ruminant nutrition research. Asian Journal of Animal Sciences 5 (1) 4655.

Kolver, E.S. \& de Veth, M.J. 2002 Prediction of Ruminal pH from Pasture-Based Diets Journal of Dairy Science. 85:1255-1266.

MTT 2011. rehutaulukot ja ruokintasuositukset [verkkojulkaisu]. Jokioinen: MTT Maa- ja elintarviketaouden tutkimuskeskus [viitattu 13.12.2011]. Saatavissa: http://www.mtt.fi/rehutaulukot.

Nagaraja, TG. \& Titgemeyer, EC. 2007. Ruminal acidosis in beef cattle: the current microbiological and nutritional outlook. Journal of Dairy Science 2007 6;90 1:17-38.

Owens, F.N., Secrists, D.S., Hill, W.J. \& Gill, D.R. 1998. Asidosis in cattle: a review. Journal of Animal Science 76: 275-286.

Penner, G.B., Beauchemin, K.A. \& Mutsvangwa, T. 2006. An evaluation of the accuracy and precision of a standalone submersible ruminal pH measurement system. Journal of Dairy Science, 89: 2132-2140.

Penner, G.B., Aschenbach, J.R., Gabel, G. \& Oba, M. 2009. Techinal note: Evaluation of a continuous ruminal pH measurement system for use in noncannulated small ruminants. Animal Science, 87: 2363-2366.

Plaizier, J.C., Krause D.O. Gozho G.N. \& McBride B.W. 2009. Subacute ruminal acidosis in dairy cow: The physiological causes, incidence and consequences. The veterinary Journal 176: 21-31. 
Sairanen, A., Juutinen, E. \& Kajava, S. 2012. Yö- ja kokoaikalaiduntamisen vaikutus lehmien syöntiin ja maitotuotokseen. Teoksessa: Maataloustieteiden päivät, 2012. 10.-11.1.2012. Suomen maataloustieteellisen seuran tiedote.

Stone, W.C. 1999. The effect of subclinical acidosis on milk components. In: Cornell Nutrition Conference for Feed Manufacturers. Cornell Univ., Ithaca, NY, 40-46s. 